Rev. bras. paleontol. 15(2):228-239, Maio/Agosto 2012

(C) 2012 by the Sociedade Brasileira de Paleontologia

doi:10.4072/rbp.2012.2.10

\title{
NEW REMAINS OF LATE PLEISTOCENE MAMMALS FROM THE CHUÍ CREEK, SOUTHERN BRAZIL
}

\author{
JAMIL CORRÊA PEREIRA \\ Museu Coronel Tancredo Fernandes de Mello, Rua Barão do Rio Branco, 467, 96230-000, \\ Santa Vitória do Palmar, RS, Brazil.jamil_pereira@terra.com.br \\ RENATO PEREIRA LOPES \\ Setor de Paleontologia, Instituto de Oceanografia, FURG, Campos Carreiros, 96201-900, \\ Rio Grande, RS, Brazil.paleonto_furg@yahoo.com.br \\ LEONARDO KERBER \\ Seção de Paleontologia, Museu de Ciências Naturais, Fundação Zoobotânica do Rio Grande do Sul, \\ Av. Dr. Salvador França, 1427, 90690-000, Porto Alegre, RS, Brazil. leonardokerber@gmail.com
}

\begin{abstract}
The Chuí Creek, located in the southernmost Brazil, is a fossiliferous outcrop known since the late 1960s, which bears important records of late Pleistocene mammals, other vertebrates and invertebrate fossils. The presence of some taxa (e.g. Hydrochoerus hydrochaeris Linnaeus, Tapirus terrestris Linnaeus, Ozotoceros bezoarticus Linneaus), although mentioned on the literature, is still to be confirmed. Specimens from Chuí Creek belonging to several collections are reexamined and new excavations and geological surveys in the area are being conducted. The new records include isolated teeth of cf. Ursidae and Rodentia (Myocastor cf. M. coypus Molina); a complete and articulated skull and jaw of a tayassuid, Catagonus Ameghino, as well as a left dentary of a juvenile ground sloth, Eremotherium $\mathrm{cf}$. E. laurillardi Lund. The ongoing systematic revision led to the confirmation of the presence of the glyptodont Doedicurus Burmeister, represented by a portion of the carapace; the cervid genera Antifer Ameghino and Morenelaphus Carette; and the equids Equus Linnaeus and Hippidion Owen, represented by cranial and dental remains. These findings expand the knowledge on the diversity of the extinct fauna found in the Chuí Creek, and have biogeographic, biostratigraphic and paleoenvironmental implications, which are herein discussed.
\end{abstract}

Key words: Quaternary, Pleistocene, megafauna, Rio Grande do Sul, Brazil.

RESUMO - O Arroio Chuí, situado no extremo sul do Brasil, é um afloramento fossilífero conhecido desde o final da década de 1960 e contém importantes registros de mamíferos, outros vertebrados e invertebrados fósseis do final do Pleistoceno. A presença de determinados táxons mencionados na literatura (e.g. Hydrochoerus hydrochaeris Linnaeus, Tapirus terrestris Linnaeus, Ozotoceros bezoarticus Linnaeus) ainda necessita confirmação. Fósseis provenientes do Arroio Chuí depositados em diferentes coleções vêm sendo revisados, e novas escavações e levantamentos geológicos vêm sendo desenvolvidos neste depósito. Os novos registros incluem dentes isolados de cf. Ursidae e Rodentia (Myocastor cf. M. coypus Molina); crânio e mandíbula completos e articulados de Catagonus Ameghino e um dentário esquerdo de Eremotherium cf. E. laurillardi Lund. A revisão sistemática levou à confirmação da presença do gliptodonte Doedicurus Burmeister, representado por parte de carapaça; de cervídeos dos gêneros Antifer Ameghino e Morenelaphus Carette, representados por galhadas incompletas; e dos equídeos Equus Linnaeus e Hippidion Owen, representados por restos cranianos e dentários. Estes achados ampliam o conhecimento sobre a diversidade da fauna extinta encontrada no Arroio Chuí, além de terem implicações biogeográficas, bioestratigráficas e paleoambientais, as quais são aqui discutidas.

Palavras-chave: Quaternário, Pleistoceno, megafauna, Rio Grande do Sul, Brasil.

\section{INTRODUCTION}

The fossil mammals from the Coastal Plain of Rio Grande do Sul State (CPRS), southern Brazil; have been known since the final of the Century XIX, after the first records by the German naturalist Hermann Von Ihering (Oliveira, 1996). In this geomorphologic unit, such remains are found in fossiliferous concentrations along the continental shelf(Lopes
\& Buchmann, 2010) and in the outcrops exposed along the banks of the Chuí Creek (Lopes et al., 2001, 2009). The fossils from the continental shelf are collected along the beach, where are thrown by storm waves, therefore do not have a precise stratigraphic context (Buchmann, 2002). Fossils of extinct mammals from the Chuí Creek were first reported in 1965, when the Departamento Nacional de Obras Contra as Secas (DNOCS) excavated and modified the course of this creek for 
irrigation purposes. During these excavations, the fossiliferous beds were exposed, and the paleontologists Carlos de Paula Couto and Fausto de Souza Cunha brought a large number of fossils to the Museu Nacional in Rio de Janeiro (Paula Couto \& Souza Cunha, 1965; Henriques, 1992).

Recently, several studies have expanded the knowledge about the fossil content, geology and biostratigraphy (e.g. Oliveira, 1992; Lopes et al., 2001; Oliveira et al., 2005; Lopes et al., 2001, 2009; Kerber et al., 2011a; Lopes, in press). In a geologic survey of the CPRS (Delaney, 1965), the fossil mammals were considered of Tertiary age, associated to the Graxaim Formation. In the same year, however, Paula Couto \& Souza Cunha (1965) correlated the fossils to the "Pampeano superior (Bonaerense)" of Argentina (late Pleistocene) (see also Soliani Jr., 1973). Posteriorly, Bombin (1975) analyzed the faunal similarity of the fossil mammals from Argentina, Uruguay and Rio Grande do Sul (RS), concluding that fossils from RS are from Lujanian Land-Mammal Age (sensu Pascual et al., 1966). Absolute ages obtained by Electron Spin Resonance (ESR) dating of fossil teeth from Chuí Creek showed results between 226 and 34 ka (Lopes et al., 2010), thus indicating that the fauna from the Chuí Creek encompasses a larger time span than was estimated before by Bombin (1975). The lithologies exposed along the banks and the taphonomic features suggest that the fossils were deposited and reworked in a meandering fluvial system (Lopes, 2009; Lopes et al., 2009).

Although studied for several years, the exact taxonomic composition of mammals from the creek is discussed. In a report about the geology and paleontology of CPRS, Paula Couto \& Souza Cunha (1965) have listed several mammalian taxa, but did not discriminate between fossils collected along the beach and those collected in the creek. In his stratigraphic and paleontologic study on this creek, Soliani Jr. (1973) presented a systematic list based on verbal communication by Carlos de Paula Couto and in the description of ungulate fossils collected by Souza Cunha (1959) along the beach.

Most of the fossils deposited in the Museu Nacional (Rio de Janeiro) by Carlos de Paula Couto and Fausto de Souza Cunha were never formally described, except for Lestodon armatus Gervais, 1855 reported by Henriques (1992) and Holmesina paulacoutoi Cartelle \& Bohórquez, 1985 described by Oliveira (1992) and Oliveira \& Pereira (2009). Other papers (e.g. Oliveira et al., 2005; Oliveira \& Pereira, 2009) have listed taxa from Chuí Creek such as Equus neogaeus Lund, 1840, Hippidion principale Lund, 1845, Ozotocerus bezoarticus Linnaeus, 1758, Blastocerus dichotomus Illiger, 1815, Antifer sp. Ameghino, 1889, Smilodon populator Lund, 1842, Megatherium americanum Cuvier, 1796, and Hydrochoerus hydrochaeris Linnaeus, 1766, whose occurrence have never been confirmed, neither formally described.

In this paper, new findings of Pleistocene mammals from Chuí Creek are described; the presence of some previously mentioned taxa are confirmed and biogeographic, biostratigraphic and paleoenvironmental implications are discussed. An updated list of known taxa is presented (Appendix 1).

\section{MATERIAL AND METHODS}

The specimens reported herein are deposited in the paleovertebrate collections of the Museu Coronel Tancredo Fernandes de Mello (Santa Vitória do Palmar, RS) and Universidade Federal do Rio Grande (FURG, Rio Grande, RS). All specimens were measured using precision calipers. Institutional abbreviations. EPM, Coleção Emidio Pinto Martino, Museu Coronel Tancredo Fernandes de Mello, Santa Vitória do Palmar, RS; LGP, Laboratório de Geologia e Paleontologia, Universidade Federal do Rio Grande, Rio Grande, RS; MCTFM, Museu Coronel Tancredo Fernandes de Mello, Santa Vitória do Palmar, RS.

\section{LOCATION AND GEOLOGICAL SETTING}

The specimens come from a fossiliferous bed exposed along the banks of Chuí Creek, located $6 \mathrm{~km}$ from Santa Vitória do Palmar municipality, in the southernmost RS, next to the border between Brasil and Uruguay (Figure 1). The creek flows in a NE-SW direction, parallell to the coastline up to the Chuí County, where it turns eastwards until reaching the Atlantic Ocean. The plain through which the creek flows is located between two Pleistocene coastal barriers: the Barrier II, located westwards and the Barrer III located eastwards of the creek. Although precise ages have not yet been determined, it is estimated that the Barrier II was formed by the $325 \mathrm{ka}$ AP marine transgression and the Barrier II by the $123 \mathrm{ka}$ AP transgression (Tomazelli et al., 2000).

The base of the sedimentary sequence exposed along the banks is constituted by shallow marine sediments, containing the ichnofossil Ophiomorpha nodosa Lundgren, 1891 and large numbers of marine shells. The layer above contains the mammalian remains; it is composed by sand with an upward increase in silt. This layer seems to have been deposited in a meandering fluvial system (Lopes et al., 2009). Although this layer is some 2,5 m thick, until now the mammalian fossils found in situ are restricted to a $\sim 1$ meter-thick horizon at its lower portion. Fossils were not found in the uppermost portion of this layer until now. At some points along the banks, just above the mammalian remains, the fossiliferous layer exhibits a 30 to $40 \mathrm{~cm}$ thick level of carbonate nodules and rhizocretions, called "Caliche Cordão" by Delaney (1965). Besides the remains found in situ, several other fossils can be found removed from the original layer due to erosion of the banks and by dredging activities. The uppermost portion of sequence is composed by a $\sim 70 \mathrm{~cm}$-thick dark, muddy sand, corresponding to the Holocene and containing archaeological artifacts (Schmitz et al., 1997).

Except for the bear canine and the equid skull, collected and donated by other persons, all remains were collected by authors on the fossiliferous level exposed along the banks of the creek. 


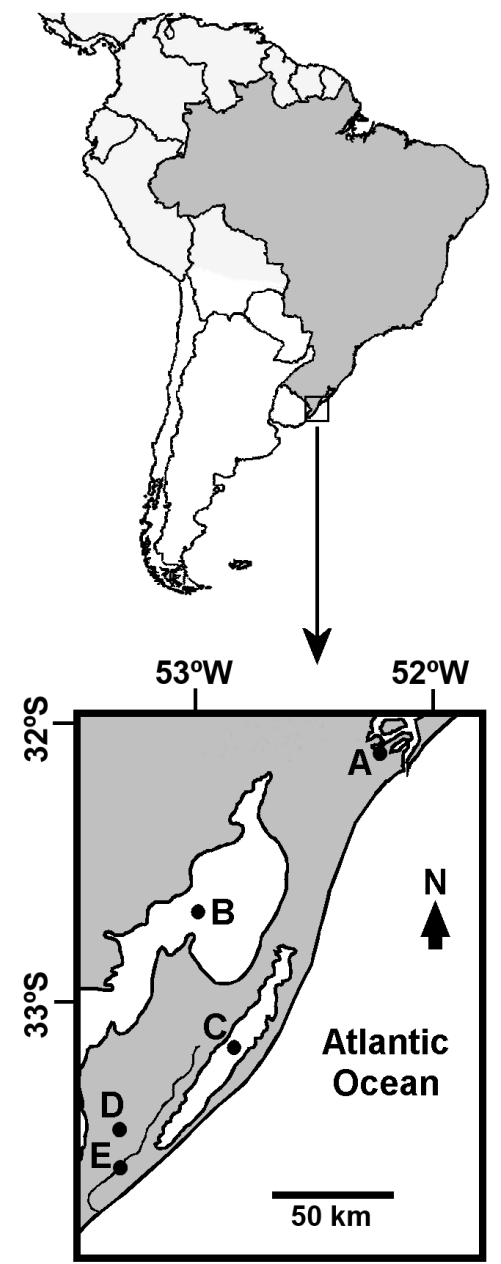

Figure 1. Detail of the coastal plain of Rio Grande do Sul State (CPRS): A, Rio Grande municipality; B, Mirim Lake; C, Mangueira Lake; D, Santa Vitória do Palmar Municipality; E, Chuí Creek.

\section{SYSTEMATIC PALEONTOLOGY}

\author{
XENARTHRA Cope, 1889 \\ PILOSA Flower, 1883 \\ MEGATHERIIDAE Owen, 1843 \\ Genus Eremotherium Spillmann, 1948
}

Eremotherium cf. E. laurillardi Lund, 1842

(Figure 2A)

Material. Left dentary (EPM-PV 0133).

Description. The dentary has the molariforms preserved, with exception of $\mathrm{m} 1$, which is fragmented. The small size of the specimen indicates that it is a juvenile. The dorsal portion of the symphysis is fragmented; the first alveolus is fragmented on both labial and lingual sides, and the remaining of the dental series is fragmented in the lingual side. The $\mathrm{m} 1$ has preserved only a fragment of its base, which shows that its distal portion was slightly convex and wider than the mesial one. The remaining molars are well preserved and all exhibit the distal side more convex than the mesial one. The $\mathrm{m} 2$ exhibit labial side slightly longer mesiodistally than the lingual one; the $\mathrm{m} 3$ exhibit subquadrate outline and is the widest one; the $\mathrm{m} 4$ bears a mesial ridge considerably wider and mesiodistally compressed than the distal one, giving it a subtriangular outline. The posterior end of the angular process and the coronoid process were not preserved. The articular condyle is partly broken, mostly the medial portion.

The specimen EPM-PV0133 is assigned as Eremotherium on the basis of the following characteres: symphysis reaching up to the $\mathrm{m} 1$ (in Megatherium Cuvier, 1796 it reaches up to the $\mathrm{m} 2$ ) and slightly projected dorsally, above the level of dental series (which is ventrally curved in Megatherium); ventral bulge of the dentary less developed than in Megatherium; a shallow sulcus between $\mathrm{m} 4$ and the ascending ramus (in Megatherium a deep sulcus); angular process posteriorly projected, at the same level of the horizontal ramus (in Megatherium dorsally projected, above the dental series) and articular condyle projected posteriorly (in Megatherium dorsally projected) (Owen, 1861; Cartelle, 1992; Cartelle \& De Iullis, 1995).

Measurements (mm). Maximum length: 217,0; length of the cheek teeth series: 80,0; dentary height (measured in the $\mathrm{m} 3$ region): 56,0 ; maximum height at the level of the mandibular condyle: 92,0 .

Comments. Two taxa of Pleistocene megatheriids are currently referred for Brazil: Megatherium americanum, restricted to RS, and Eremotherium laurillardi, which inhabited the intertropical areas of Americas (Cartelle \& DeIuliis, 1995). The fossil record of Eremotherium is common in the intertropical region of Brazil (e.g. Cartelle \& DeIullis, 1995; Dantas \& Zucon, 2005; Dantas \& Zucon, 2007; Dantas \& Tasso, 2007; Ribeiro \& Carvalho, 2009), with only one previous record for southern Brazil (Toledo, 1986). Cartelle (1992) stated that the morphological characters of Eremotherium do not differ considerably between juveniles and adults, thus the specimen reported here is assigned to this genus. It probably represents E. laurillardi, the only valid species from the Brazilian Pleistocene (Cartelle \& DeIuliis, 1995). The southernmost record of this species was in Caçapava do Sul municipality, located in the central area of RS, some $400 \mathrm{~km} \mathrm{NW}$ of Chuí Creek (Toledo, 1986); thus, the record of Eremotherium in the outcrops of Chuí Creek expands its known paleogeographic distribution being in this way the southernmost record for the Americas until now.

CINGULATA Illiger, 1881

GLYPTODONTIDAE Burmeister, 1879

Genus Doedicurus Burmeister, 1874

Doedicurus sp.

(Figure 2B)

Material. Fragment of carapace (MCTFM-PV 0445).

Description. The specimen presents about 13 fused osteoderms. The sutures between them are barely discernible. Each osteoderm has $30-50 \mathrm{~mm}$ in diameter and bears $5-6$ pilose foramina measuring about $5 \mathrm{~mm}$ in diameter. The osteoderms of Doedicurus are distinguished by the presence of large foramina in a circle on the central portion. Differently 
from other glyptodonts, such as Glyptodon and Panochthus, their surface is smooth without ornamentation.

Comments. The occurrence of Doedicurus in Brazil is restricted to RS (Paula Couto 1975, 1979), and the known specimens come mostly from the continental shelf. This taxon is rare in comparison to Glyptodon and Panochthus, what also happens among the remains from Chuí Creek. The only previous record of this taxon in Chuí Creek was presented by Oliveira (1992).

RODENTIA Bowdich, 1821

HYSTRICOGNATHI Tullberg, 1899

CAVIOMORPHA Wood \& Patterson (in Wood, 1955) ECHIMYIDAE Gray, 1825

MYOCASTORINAE Ameghino, 1904

Genus Myocastor Kerr, 1792

Myocastor cf. M. coypus (Molina, 1782)

(Figure 2C)

Material. Right M2 (MCTFM-PV 0732).

Description. The specimen is protohypsodont, with rectangular outline and all flexi open. The hypoflex is extended up to the middle of the occlusal surface, and is opposite to the protoloph, between the paraflex and the mesoflex, as described for Myocastor (Verzi et al., 2002). The labial flexi (paraflex and mesoflex) have the same size than the hypoflex, while the metaflex is more developed, reaching almost the entire width of the occlusal surface. The characters observed in this specimen are the same of $M$. coypus; however, due to the scarcity of the material, it is assigned to Myocastor cf. M. coypus.

Measurements (mm). Maximum height: 12,9; mesiodistal length: 8,14; labiolingual width: 7,04.

Comments. The previous record of fossil rodents from Chuí Creek is very scarce, represented by cranial and postcranial remains of Microcavia Gervais \& Ameghino, 1880 described by Ubilla et al. (2008) and remains of Dolichotinae indet. and Lagostomus Brookes, 1828 reported by Kerber et al. (2011a). The stratigraphic distribution of Myocastor extends from the late Miocene (Mesopotamian) (Candela \& Noriega, 2004) to Recent. For Pleistocene assemblages, Myocastor have been reported for Bolivia, Uruguay, Argentina and Brazil (Frailey et al., 1980; Ubilla, 2004; Ferrero \& Noriega, 2009). Rodrigues \& Ferigolo (2004) described remains of M. coypus from the continental shelf of RS, and Kerber et al. (2011b) referred remains of Myocastor sp. from the continental upper Pleistocene beds from RS. The extant $M$. coypus lives in permanently wet environments of Uruguay, Argentina, Chile and southern Brazil (Woods et al., 1992).

CARNIVORA Bowdich, 1821 cf. URSIDAE Fischer de Waldheim, 1817 (Figure 2D)

Material. Complete right upper canine (MCTFM-PV 0710). Description. The specimen is large and exhibits wear on the crown apex, exposing dentine. The crown represents $1 / 3$ of the tooth, and bears a distinct ridge on the mesial side. The cross section is subcircular, and the root is wider at its middle, becoming narrower towards the base. The root is closed, a little narrower than the limit of the crown. The root exhibit surface crackings that suggest weathering.

Measurements (mm). Maximum height: 99,0; crown height: 40,0; mesiodistal length (at the crown base): 25,0; labiolingual width (at the crown base): 22,0; maximum diameter: 32,0.

Comments. Fossil remains of Carnivora are very scarce in RS. The previous record of this group in CPRS is almost exclusively from the continental shelf. It includes the felid Smilodon populator Lund, 1842; the pinnipeds Arctocephalus sp. Saint-Hilaire \& Cuvier, 1826 and Otaria byronia Blainville, 1820; and the canids Dusicyon cf. avus and Theriodictis sp. Mercerat, 1891 (Moreira, 1970; Oliveira \& Drehmer, 1997; Drehmer \& Ribeiro, 1998; Rodrigues et al., 2004). From the Chuí Creek, the only records so far are Protocyon troglodytes and Dusicyon avus Burmeister, 1866 (Oliveira et al., 2005; Pereira et al., 2011). Paula Couto (1975) mentioned the presence of $S$. populator in the "Santa Vitória Formation", but did not specify whether the specimen came from the Chuí Creek or from the continental shelf.

In South America, the Ursidae are recorded from the early Pleistocene to the Recent, and represented by the extinct genus Arctotherium, the only valid Pleistocene taxon (Soibelzon, 2004; Soibelzon et al., 2005) and the living Tremarctus ornatus Cuvier, 1825 in Geoffroy St. Hilaire \& Cuvier, 1825.

$$
\begin{aligned}
& \text { ARTIODACTYLA Owen, } 1848 \\
& \text { CERVIDAE Gray, } 1821 \\
& \text { Genus Antifer Ameghino, } 1889 \\
& \text { Antifer sp. } \\
& \text { (Figures 3A-B) }
\end{aligned}
$$

Material. Incomplete antler (MCTFM-PV 0581); fragment of the base of an antler (LGP-I0003).

Description. Both specimens are assigned as Antifer by their large dimensions and presence of surface ornamentation in the form of well-marked longitudinal grooves, with small tubercles at the base (Castellanos, 1945). The specimen MCTFM-PV 0581 is an almost complete right antler (Figure $3 \mathrm{~A})$, concave on the medial side and convex on the lateral one. The medial surface bears a longitudinal depression; the $1^{\text {st }}$ ramification is mediolaterally flattened, and the rami are subcircular in cross section. At the height of the $2^{\text {nd }}$ ramification the axis of the antler is flattened mediolaterally, giving it a subrectangular cross section. The specimen LGP-I0003 consists of the basal portion of a left antler (Figure 3B), longitudinally broken on the posterior side.

Measurements (mm). MCTFM-PV 0581. Maximum height: 440,0; height of the bifurcation: 163,0; maximum anteroposterior and transversal diameters: 58,0 and 53,0, respectively. LGP-I0003. Maximum height: 68,5; anteroposterior diameter: 34,0; transversal diameter: 35,0 .

Comments. The morphological features of the specimen 

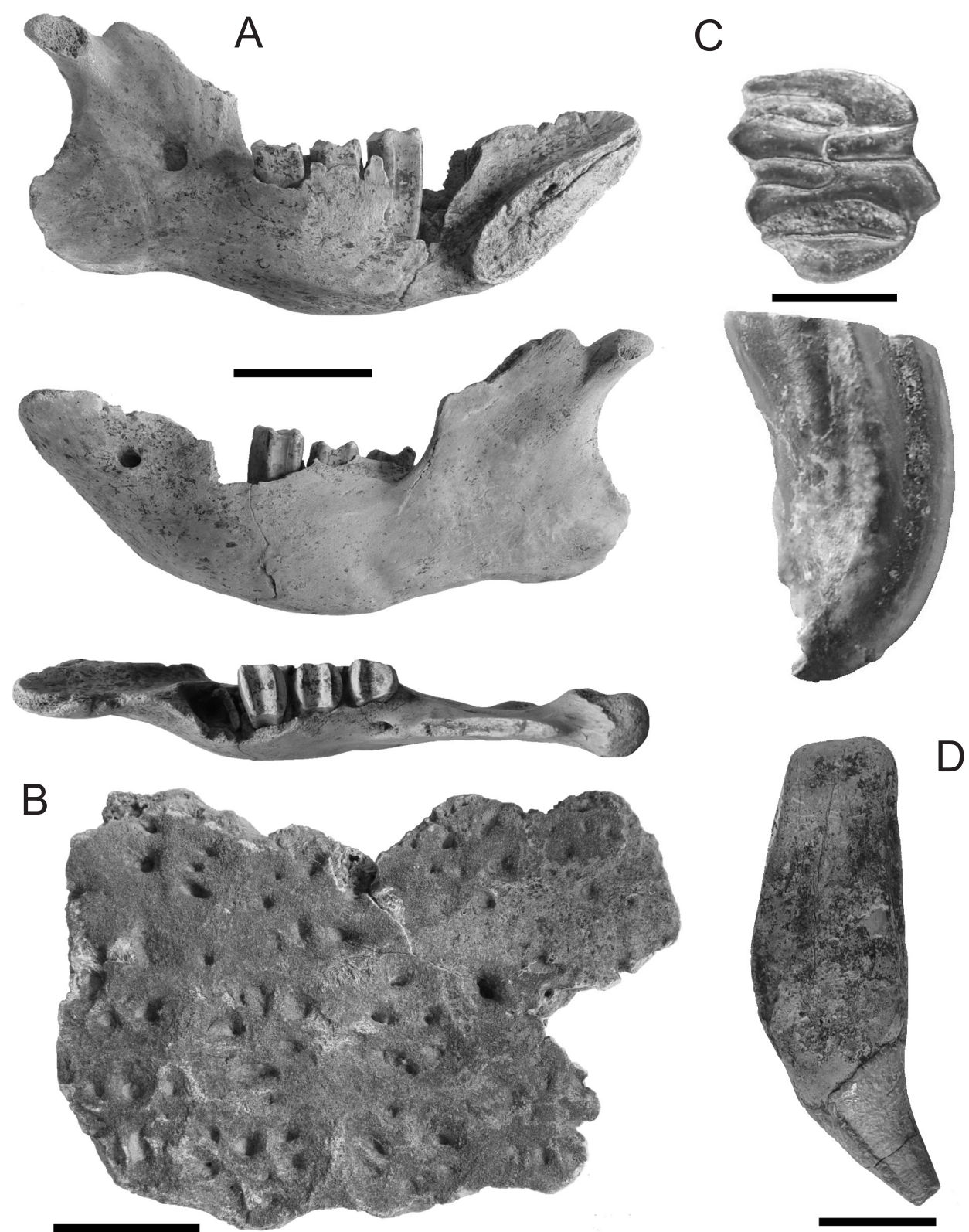

Figure 2. A, Eremotherium cf. E. laurillardi. EPM-PV 0133, left dentary in mesial, lateral and occlusal views. B, Doedicurus sp. MCTFM-PV 0445, fragment of the carapace in external view. C, Myocastor cf. M. coypus. MCTFM-PV 0732, right M2 of in occlusal and lingual views. D, cf. Ursidae. MCTFM-PV 0710, upper right canine in mesial view. Scale bars: A-B = 50 mm; C = $5 \mathrm{~mm} ; \mathrm{D}=25 \mathrm{~mm}$.

MCTFM-PV 0581 are similar to the description of Antifer ultra (Ameghino, 1888) by Castellanos (1945). The distinction between the two species of this genus recognized by Ameghino, A. ensenadensis (Ameghino, 1888) and A. ultra, is based on size differences between both, but it is possible that these are only a result of intraspecific variations (Menégaz, 2000). In the Buenos Aires Province of Argentina, the genus Antifer is restricted to Ensenandan Stage/Age (A. ensenadensis) and Bonaerian Stage/Age (A. ultra) (Cione \& Tonni, 1999; Cione et al., 1999). However, this taxon has been reported for the late Pleistocene of northern Chile (Quebrada Quereo Formation, Labarca \& López, 2006), Argentine Mesopotamian (Toropí Formation, Alcaraz \& Zurita, 2004; Tezanos Pinto Formation, Ferrero \& Noriega, 2009; El Palmar Formation, Ferrero et al., 2007), Uruguay (Sopas Formation, Ubilla, 2004) and western
RS (Touro Passo Creek, Scherer et al., 2007; Kerber \& Oliveira, 2008a). This fact suggests that Antifer may have survived in the late Pleistocene of this area (Lopes \& Pereira, 2009).

Genus Morenelaphus Carette, 1922

Morenelaphus sp.

(Figures 3C-K; Table 1)

Material. Incomplete antlers (MCTFM-PV 0578 e MCTFMPV 0579) and basal fragments of antlers (EPM-PV 0106, EPM-PV 0145, MCTFM-PV 0534, LGP-I0005, LGP-I 0006 and LGP-I 0008).

Description. These specimens are smaller in comparison to specimens of Antifer and the surface ornamentation is less 
evident; slightly curved in "S", as described for Morenelaphus (see Figure 3 C') (Kraglievich, 1940; Menégaz \& Ortiz Jaureguizar, 1995); and less robust than Blastocerus Wagner, 1844. The angle between the axis and the $1^{\text {st }}$ ramification is more open than that of Antifer. Specimen MCTFM-PV0578 (Figures $3 \mathrm{C}, \mathrm{C}^{\prime}$ ) is still attached to a skull fragment, portions of occipital and parietal regions. Specimen MCTFM-PV0579 (Figures 3D, D') also bears part of the skull, but smaller; the space between the rosette and the $1^{\text {st }}$ ramus is large, and the axis is less sinuous in comparison to the specimen MCTFM- PV0578. Specimen LGP-I0005 is the only fossil known so far from the Chuí Creek that exhibits carbonate concretions on its surface (Lopes, 2009). Comments. In previous publications (e.g. Paula Couto \& Souza Cunha, 1965; Soliani Jr., 1973; Souza Cunha \& Magalhães, 1981), the presence of the cervids Morenelaphus and Ozotoceros Ameghino, 1889 was mentioned for the Chuí Creek. Oliveira et al. (2005) listed Antifer and Ozotoceros for Chuí Creek, but they not referred and described the materials. Scherer et al. (2007), in a review of the fossil cervids from the CPRS, did not identify remains of Ozotoceros. Here we confirmed the presence of Antifer and Morenelaphus in the Chuí Creek. Besides the remains described here, there are several other cervid fragments that could not have been conclusively identified either as Antifer, Morenelaphus or other genera.

Table 1. Measurements ( $\mathrm{mm}$ ) of the specimens of Morenelaphus Abbreviations: $\mathbf{M H}$, maximum height; $\mathbf{B H}$, height of the bifurcation; AD, maximum anteroposterior diameter (measured above the rosette); TD, maximum transverse diameter (above the rosette).

\begin{tabular}{lcccc}
\multicolumn{1}{c}{ Specimen } & MH & BH & AD & TD \\
\hline MCTFM-PV 0578 & 250.0 & 46.0 & 38.0 & 29.0 \\
MCTFM-PV 0579 & 245.0 & 71.0 & 30.0 & 27.0 \\
EPM-PV 0106 & 57.0 & 44.0 & 21.0 & 16.0 \\
EPM-PV 0145 & 53.0 & 41.0 & 29.0 & 24.0 \\
MCTFM-PV 0584 & 84.0 & 47.0 & 17.0 & 16.0 \\
LGP-I0005 & 91.5 & 54.0 & 27.0 & 22.0 \\
LGP-I0006 & 97.5 & 49.0 & 27.0 & 21.5 \\
LGP-I0008 & 83.5 & 59.0 & 33.0 & 30.0 \\
\hline
\end{tabular}

TAYASSUIDAE Palmer, 1897

Genus Catagonus Ameghino, 1904

Catagonus sp.

(Figure 4A)

Material. Skull (MCTFM-PV 0575a) and mandible (MCTFM-PV 0575b).

Description. The skull is almost complete, with the right side best preserved, lacking the canine and I2, and with the I1 broken. The left side was partially destroyed by weathering. In the mandible, the right ramus is well preserved, but without canine, incisors and $\mathrm{m} 2$; the posterior portion of the left side was destroyed by weathering. Among the diagnostic characteristics of the genus Catagonus are the convex dorsal profile of the nasal portion of the rostrum and the orbit posteriorly displaced some $34 \mathrm{~mm}$ in relation to the M3 (Gasparini et al., 2009).
Measurements (mm). MCTFM-PV 0575a. Skull, total length: 315,0; maximum height: 114,0; upper cheek teeth length: 74,0. MCTFM-PV 0575b. Mandible, total length: 168,0; height at the condyle: 93,0; lower cheek teeth length: 80,0.

Comments. In South America, the Tayassuidae have a stratigraphic distribution that range from late Pliocene to Recent, and is represented by three genera (Gasparini, in press): Platygonus Le Conte, 1848, Tayassu Fischer, 1814, and Catagonus. Only the last two have living representatives. The living species Catagonus wagneri Rusconi, 1930 was discovered only in the 1970s (Wetzel et al., 1975). Fossils of Catagonus have been reported for Pleistocene of Bolivia, Argentina and Uruguay (Gasparini, in press); in Brazil it has been recorded for caves of Minas Gerais, Tocantins and Paraná states and Touro Passo Creek (RS) (Paula Couto, 1981; Gasparini et al., 2009; Silva et al., 2010; Ávilla et al., 2010). The current distribution of $C$. wagneri is restricted to the Chaco, in Paraguay and Bolivia, where semi-arid conditions are predominant (Mayer \& Brant, 1982; Mayer \& Wetzel, 1986). The wide paleobiogeographic distribution of Catagonus can be related to the presence of dryer environments during the Pleistocene (Menégaz \& Ortiz Jaureguizar, 1995). This specimen needs a more comparative study to determine its specific status, as well as, a complete description of its anatomic features.

\section{PERISSODACTYLA Owen, 1848 EQUIDAE Gray, 1821 \\ Genus Equus Linnaeus, 1758}

Equus cf. E. (A.) neogaeus Lund, 1840 (Figures 4B-C)

Material. Incomplete skull (MCTFM-PV 0618).

Description. The specimen represents part of the rostral portion of a skull, without incisors but with the left canine and cheek teeth series preserved (lacking the M2 and M3). The nasals are fractured, but it is visible that the retraction of the nasal fissure begins anteriorly to the P2, differently from Hippidion which have a long fissure reaching at least the M2 or M3 (Alberdi \& Prado, 1992; Alberdi et al., 2003). The palatal surface is flattened and the incisive foramina are located slightly anteriorly to the canine. The parastyle and mesostyle are well developed and bigger than the metastyle on both P2 and P3. In the M1 the parastyle is absent. The lingual sides of the anterofossae and posterofossae have poorly developed plis, except for the anterofossa of the P2. The hypocone is oval, with a constriction that separates itself from the the metaloph, except on the M1. The outline of the protocone on the $\mathrm{P} 2$ is oval on its distal end, while on the $\mathrm{P} 3$, P4 and M1 it is subtriangular, with distal end more developed than the mesial one, differently from Hippidion, which bears an oval protocone.

Measurements (mm). Mesiodistal length (MDL) of the P2: 35,0; Labiolingual width (LLW) of the P2: 22,0; MDL of the P3: 23,0; LLW of the P3: 27,0; MDL of the P4: 21,0; LLW of the P4: 24,0; MDL of the M1: 20,0; LLW of the M1: 23,0. 

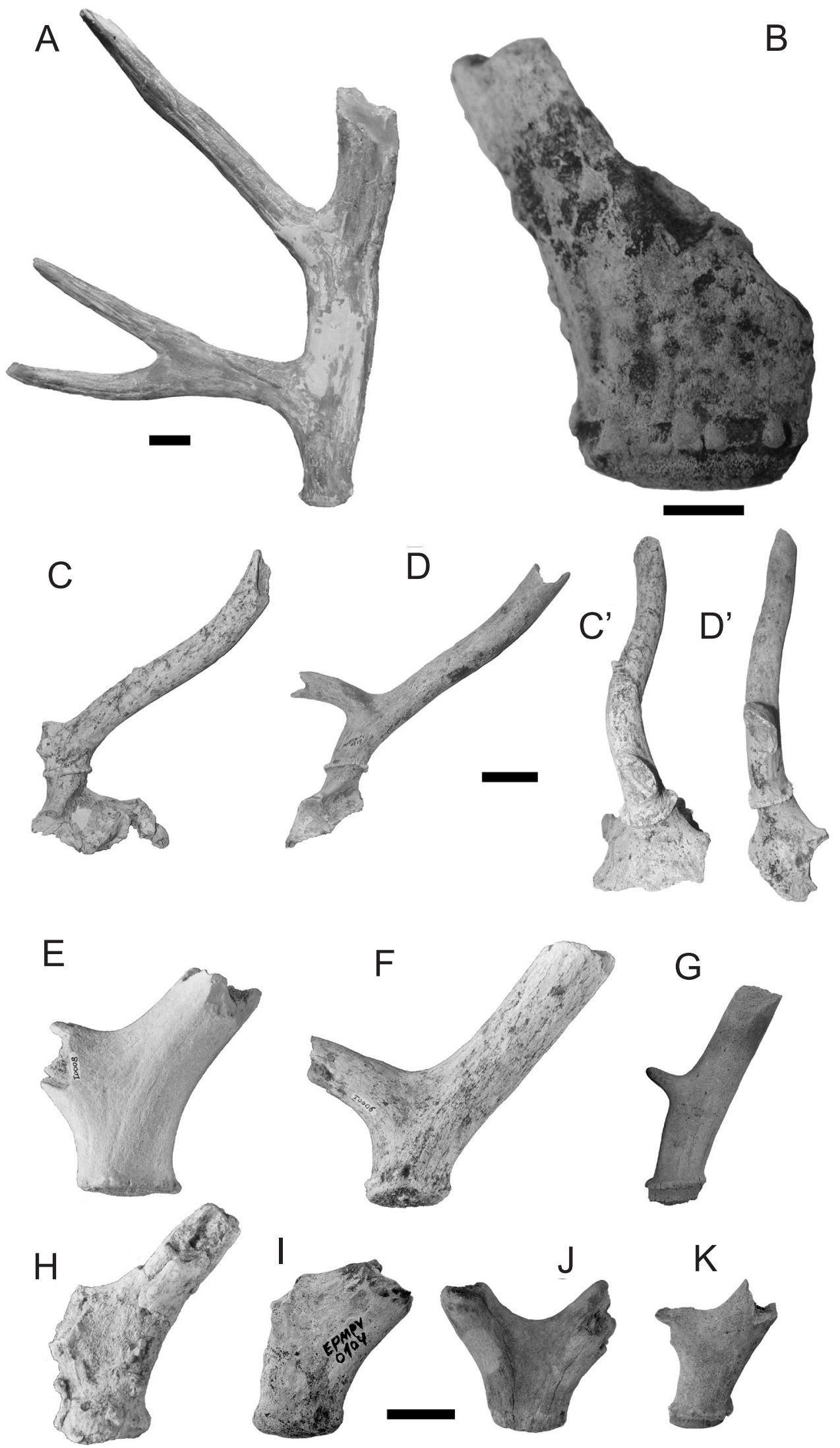

Figure 3. Antifer sp. A, MCTFM-PV 0581, antler in medial view; B, LGP-I 0003, basal fragment of an antler in lateral view. Morenelaphus sp. C, MCTFM-PV 0578, fragmented antler plus a portion of the skull of in lateral (C) and anterior (C') views; D, MCTFM-PV 0579, antler in lateral (D) and anterior (D') views; E-K, fragments of antlers in lateral views, LGP-I0008 (E); LGP-I0006 (F); MCTFM-PV 0534 (G); LGP-I0005 (H); EPM-PV 0104 (I); EPM-PV 0145 (J); EPM-PV 0106 (K). Scale bars: A, C-D' = 50 mm; B = 10 mm; E-K = 25 mm. 
Genus Hippidion Owen, 1869

\section{Hippidion sp.}

(Figure 4D)

Material. Upper molar (M1?), (EPM-PV 0137).

Description. The specimen consists of a partial crown of the tooth. The material is diagnosed as Hippidion by the presence of an oval-shaped protocone (Alberdi \& Prado, 1992). The occlusal surface exhibits a labiolingual depression between the metacone and paracone. The parastyle and mesostyle are well developed, and the metastyle is absent. The hypocone is poorly developed. The tooth is longitudinally curved, concave on the lingual side. The distal side exhibit bioerosion traces as irregular sulci near the occlusal surface, possibly caused by plant roots or worms. Part of the enamel on the mesial side was lost, and the presence of longitudinal crackings suggests weathering.

Measurements (mm). Maximum height: 53,0; mesiodistal length: 27,0; labiolingual width: 29,0.

Comments on the equids. According to the review of South American equids by Alberdi \& Prado (1993) and Prado \& Alberdi (1994), two genera are recognized, Hippidion and Equus. Hippidion is represented by three species: $H$. devillei (Gervais, 1855), H. principale and H. saldiasi Roth,
1899. Equus (Amerhippus) is represented by five species: E.(Amerhippus) neogaeus, E. (Amerhippus) insulatus C. Ameghino (in F. Ameghino 1904), E. (Amerhippus) santaeelenae Spillmann, 1938, E. (Amerhippus) andium Branco, 1883 and E. (Amerhippus) lasallei Daniel, 1948. For Brazil, only $H$. devillei, $H$. principale and $E$. (A.) neogaeus are referred (Alberdi et al., 2003). In RS, Hippidion was previously reported for Touro Passo Creek, Sanga da Cruz and the Continental Shelf; and E. (A.) neogaeus for Quaraí River, Garupá Creek, Touro Passo Creek and the continental shelf (Oliveira, 1992; Scherer \& Da Rosa, 2003; Kerber \& Oliveira, 2008a,b). The material here reported confirms the presence of these taxa in the Chuí Creek. E. (A.) neogaeus, the only species of Equus recorded in late Pleistocene of southern South America, is considered the fossil-guide of the Lujanian Stage/Age of the Pampean Region (Tonni, 2009). The equids are indicatives of open areas and grasslands (Alberdi \& Prado, 1992).

\section{FINAL REMARKS}

The remains here reported contribute to the knowledge of the fossil mammals from Chuí Creek. Some specimens are new records (Eremotherium, Myocastor, cf. Ursidae, Catagonus), while others confirm the presence in this area of
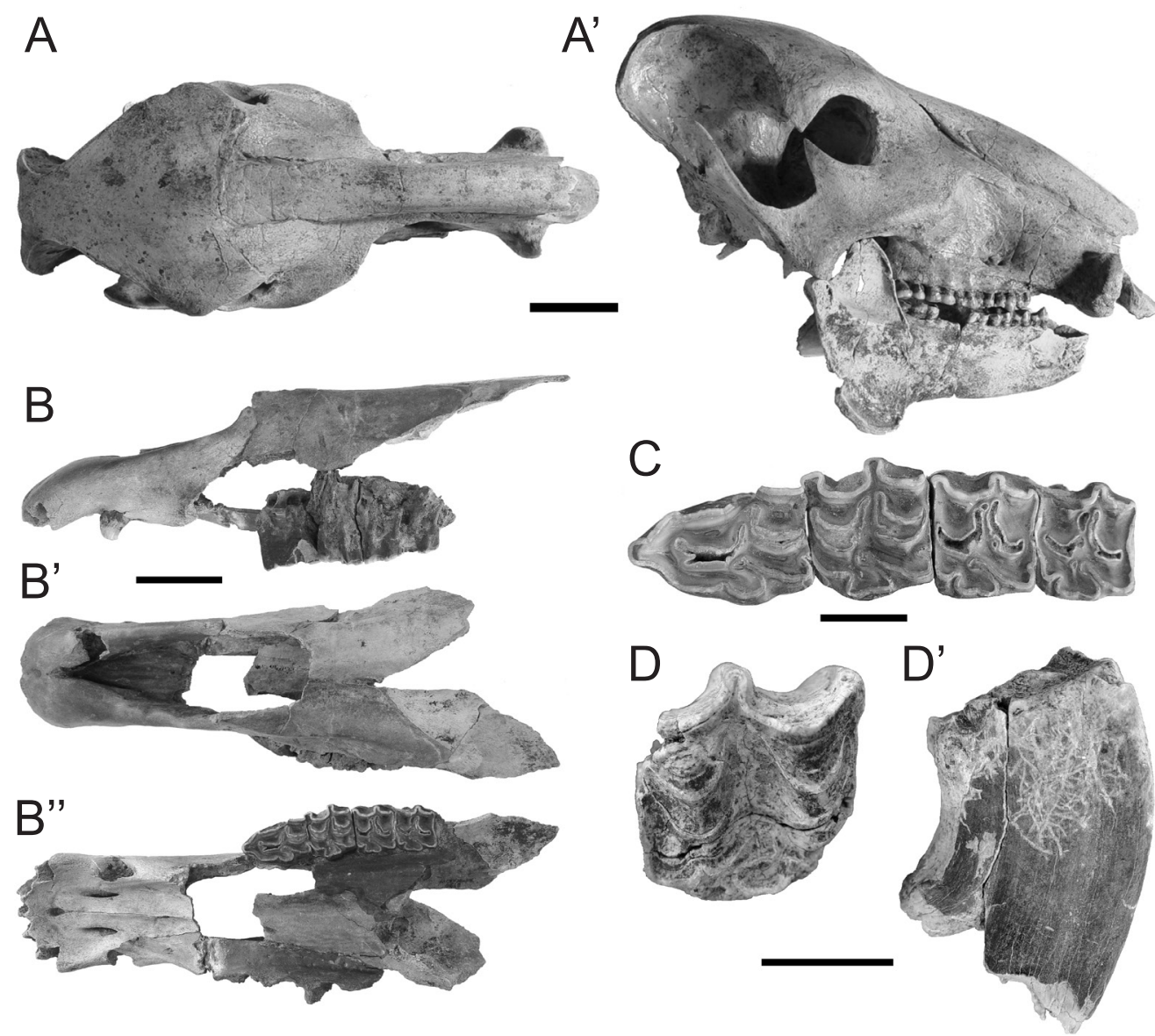

Figure 4. Catagonus sp. A-A', skull and mandible of MCTFM-PV 0575a, b in dorsal (A) and lateral views (A'). Equus cf. E. (A.) neogaeus. B-C, portion of the skull of MCTFM-PV 0618 in lateral (B), dorsal (B') and ventral (B') views; detail of the cheek teeth series (C). Hippidion sp. D-D', molar of EPM-PV 0137 in occlusal (D) and distal views (D') (scale bar $=20 \mathrm{~mm}$ ). Scale bars: A-B = $50 \mathrm{~mm}$; C-D = $20 \mathrm{~mm}$. 
certain taxa that have been previously mentioned but never formally published, such as Antifer, Morenelaphus, Equus and Hippidion. This report increases the known taxonomic diversity of the fossil assemblage from the creek and contributes to a better understanding of faunal and climatic changes in the coastal area of southern Brazil during the Late Pleistocene.

The occurrence of Eremotherium increases the number of intertropical (Brazilian) taxa known from Chuí Creek, together with Protocyon troglodytes, Propraopus sulcatus, Pampatherium humboldti, Holmesina paulacoutoi and Catonyx cf. C. cuvieri (Oliveira et al., 2005; Oliveira \& Pereira, 2009; Lopes \& Pereira, 2010), besides increasing its distribution. The presence of Myocastor in this assemblage indicates the existence of perennial wet environments during some phase in the past, which seem to corroborate the interpretation that most remains were preserved and reworked in fluvial systems (Lopes et al., 2001; 2009). On the other hand, the fossil assemblage of Chuí Creek contains fossils of Pampean taxa such as Doedicurus sp., Macrauchenia patachonica, and Lestodon sp. and also taxa that indicate semi-arid environments such as the Dolichotinae, Lagostomus cf. L. maximus, Microcavia sp. and Catagonus (Ubilla et al., 2008; Kerber et al.,2011a; Lopes, in press).

Besides southern Brazil, northern Uruguay and the Mesopotamian region of Argentina have also shown a similar faunal composition during the Late Pleistocene, characterized by the co-occurrence of taxa of Pampean and Brazilian affinities. This pattern has been pointed by several authors (e.g. Oliveira, 1996; 1999; Carlini et al., 2004; Ubilla et al., 2004; Gasparini \& Zurita, 2005; Kerber \& Oliveira, 2008a; Ferrero \& Noriega, 2009; Oliveira \& Kerber, 2009; Oliveira \& Pereira, 2009) and is likely to be caused by the latitudinal displacement of climatic belts and corresponding environments, correlated to glacial-interglacial cycles. Several pollinical studies show that cold-tolerant vegetation found today in southern Brazil migrated up to $750 \mathrm{~km}$ northwards during the last glacial maximum (LGM), which probably also occurred during past glacials (Lopes, in press). It is likely that Pampean taxa followed these latitudinal migrations, thus reaching areas to the north of the Pampean Region. The presence of intertropical taxa in southern Brazil, Uruguay and Argentina permit to suggest that the opposite also occurred, with southwards migration of warmer climates, either during full interglacials but also during interstadials. Tapirids, for example, appear in the fossil record of the Pampean Region during the Ensenadan Stage / Age, between $\sim 2$ myr and $~ 780$ kyr BP (Cione \& Tonni, 1999), but their current distribution is much farther to the north.

One major problem that hampered the bio- and chronostratigraphic correlations of the Pleistocene faunas of the region is the lack of absolute ages for most deposits. Lopes et al. (2010) published dating between $226 \mathrm{kyr}$ and $34 \mathrm{kyr}$ BP for the assemblage of Chuí Creek obtained by electron spin resonance (ESR) datings on teeth. These ages indicate that the fauna encompasses the final part of an interglacial, correlated to marine isotope stage (MIS) 7, two interglacials (MIS 5 and
3) and two glacials (MIS 6 and 4). Taking into account these datings, it seems reasonable to argue that the intertropical fauna may have reached the area of Chuí Creek during the climatic optimum of MIS 5 (Eeemian stage, between 131 and 114 kyr BP) or during one of warmer climate fluctuations (interstadials) of MIS 3.

Besides the lacking of absolute datings, another problem for a batter understanding of paleoenvironmental and paleoclimatic conditions at Chuí Creek is the fact that most remains have been reworked due to erosion of the banks by fluvial activities. Geological and taphonomic studies in Chuí Creek indicate that the fossiliferous level represents meandering fluvial systems that have reworked most of the remains, thus removing them from their original stratigraphic setting. Nevertheless, the stratigraphic successions exposed along the banks of the creek seem to indicate environmental modifications related to the climatic changes during Late Pleistocene. Until now, no mammalian remains, but only traces of plant roots have been found so far above the $\sim 1$ meter-thick fossiliferous horizon. The absence of vertebrate remains, the high silt content and the presence of carbonate nodules and concretions in some points along the banks, seem to indicate that the climate changed to more dry and arid conditions, which may have contributed to the disappearance of large mammals in the area.

The continuous research efforts in this area, focusing on stratigraphy, fossil collecting, mineralogical and palynological analyses, are likely to provide new information regarding the mammalian community from southernmost Brazil permitting to establish comparisons with other fossil localities in order to understand the responses of this community to the climatic changes in the late Pleistocene.

\section{ACKNOWLDEGEMENTS}

The authors would like to thank to CNPq (Conselho Nacional de Pesquisa e Tecnologia) for finantial support to L.K. and R.P.L as fellowships of the Programa de Pósgraduação at Universidade Federal do Rio Grande do Sul. To H. Rodrigues and E. Arriada for the kind donation of the ursid and equid specimens, respectively; to L. Soibelzon and A. Alcaraz for helping with the identification of some specimens, to A.M. Ribeiro, D. Silva, V.G. Pitana and J. Ferigolo for their useful comments on the manuscript and to M. Ubilla and other anonymous referee for their reviews.

\section{REFERENCES}

Alberdi, M.T.; Cartelle, C. \& Prado, J.L. 2003. El registro Pleistoceno de Equus (Amerhippus) e Hippidion (Mammalia, Perissodactyla) de Brasil. Consideraciones paleoecológicas y biogeográficas. Ameghiniana, 40:173-196.

Alberdi, M.T. \& Prado, J.L. 1992. El registro de Hippidion Owen, 1869 y Equus (Amerhippus) Hoffstetter, 1950 (Mammalia, Perissodactyla) en América del Sur. Ameghiniana, 29:265-284.

Alberdi, M.T. \& Prado, J.L. 1993. Review of the genus Hippidion Owen, 1869 (Mammalia: Perissodactyla) from the Pleistocene of South America. Zoological Journal Linnean Society, 108:1-22. 
Alcaraz, M.A. \& Zurita, A.E. 2004. Nuevos registros de cérvidos poco conocidos: Epieuryceros cf. proximus Castellanos y Antifer sp. (Mammalia, Artiodactyla, Cervidae). Revista del Museo Argentino de Ciencias Naturales (nueva série), 6:43-50.

Avilla, L.S.; Muller L. \& Gasparini, G.M. 2010. O registro mais boreal de Catagonus stenocephalus (Lund in Reinhardt, 1880) (Mammalia, Tayassuidae) na América do Sul. In: JORNADAS FLUMINENSE DE PALEONTOLOGIA, 5, 2010. Livro de Resumos, Rio de Janeiro, p 50.

Bombin, M. 1975. Afinidade paleoecológica, cronológica e estratigráfica do componente de megamamíferos na biota do Quaternário terminal da Província de Buenos Aires, Uruguai e Rio Grande do Sul (Brasil). Comunicações do Museu de Ciências da PUCRS, 9:1-28.

Buchmann, F.S.C. 2002. Bioclastos de organismos terrestres e marinhos na praia e Plataforma Interna do Rio Grande o Sul: natureza, distribuição, origem e significado geológico. Programa de Pós-Graduação em Geociências, Universidade Federal do Rio Grande do Sul. PhD. thesis, 108 p.

Candela, A.M. \& Noriega, J.I. 2004. Los coipos (Rodentia, Caviomorpha, Myocastoridae) del "Mesopotamiense" (Mioceno tardío; Formación Ituzaingó) de la provincia de Entre Ríos, Argentina. Insugeo, Miscelánea, 12:77-82.

Carlini, A.A.; Zurita, A.E.; Gasparini, G. \& Noriega, J.I. 2004. Los mamíferos del Pleistoceno de la mesopotamia argentina y su relación tanto con aquellós del centro norte de Argentina, Paraguay y sur de Bolivia, con los del Sur de Brasil y Oeste de Uruguay: paleogeografía y paleoambientes. Insugeo, Miscelánea, 12:5-12.

Cartelle, C. 1992. Os Edentata e megamamíferos da Toca dos Ossos (Ourolândia, BA). Programa de Pós-Graduação em Morfologia, Universidade Federal de Minas Gerais, Ph.D. thesis, 700 p.

Cartelle, C. \& De Iullis, G. 1995. Eremotherium laurillardi: the panamerican Late Pleistocene megatheriid sloth. Journal of Vertebrate Paleontology, 15:830-841.

Castellanos, A. 1945. Notas sobre algunas cornamentas de ciervos de los géneros Epieuryceros, Antifer y Paraceros y descripción de la de Epieuryceros proximus n. sp. Publicaciones del Instituto de Fisiografía y Geología de La Facultad de Ciencias Físicas, Químicas y Naturales Aplicadas a la Industria de la Universidad Nacional del Litoral, 24:5-23.

Cione, A.L. \& Tonni, E.P. 1999. Biostratigraphy and chronological scale of upper-most Cenozoic in the Pampean Area, Argentina. In: J. Rabassa \& M. Salemme (eds.) Quaternary of South America and Antarctic Peninsula, A.A. Balkema, p. 23-51.

Cione, A.L.; Tonni, E.P.; Bond, M.; Carlini, A.; Pardiñas, U.F.J.; Scillato-Yané, G.; Verzi, D. \& Vucetich, M.G. 1999. Occurrence charts of Pleistocene mammals in the Pampean area, eastern Argentina. In: J. Rabassa \& M. Saleme (eds.) Quaternary of South America and Antarctica Peninsula, A.A. Balkema, 1999. p. 53-59.

Dantas, M.A.T. \& Tasso, M.A.L. 2007. Megafauna do Pleistoceno final de Vitória da Conquista, Bahia: taxonomia e aspectos tafonômicos. Scientia Plena, 3:30-36.

Dantas, M.A.T. \& Zucon, M. H. 2005. Sobre a ocorrência de dois taxa pleistocênicos na Fazenda Tytoya, Poço Redondo, Sergipe. Scientia Plena, 1:92-97.

Dantas, M.A.T. \& Zucon, M. H. 2007. Sobre a ocorrência de fósseis da megafauna do Pleistoceno final em Coronel João Sá, Bahia, Brasil. Revista da Universidade Guarulhos, 6:191-200.

Delaney, P.J.V. 1965. Fisiografia e Geologia de Superfície da Planície Costeira do Rio Grande do Sul. Publicação Especial da Escola de Geologia, UFRGS, 6:1-105.

Drehmer, C.J. \& Ribeiro, A.M. 1998. A temporal bone of an Otariidae (Mammalia, Pinnipedia) from the late Pleistocene of Rio Grande do Sul State, Brazil. Revista Universidade Guarulhos, 3:39-44.

Ferrero, B.S. \& Noriega, J.I. 2009. La paleontologia de vertebrados en el Quaternario de la Província de Entre Rios (Argentina): estado actual y perspectivas. In: A.M. Ribeiro; S.G. Bauermann \& C.S. Scherer (orgs.) Quaternário do Rio Grande do Sul Integrando Conhecimentos. Monografias da Sociedade Brasileira de Paleontologia, 1:205-215.

Ferrero, B.S.; D. Brandoni, D.; Noriega, J.I. \& Carlini, A.A. 2007. Mamíferos de la Formación El Palmar (Pleistoceno tardío) de la provincia de Entre Ríos. Revista del Museo Argentino de Ciencias Naturales, 9:109-117.

Frailey, D.; Campbell, K.E. \& Wolff, R.G. 1980. Additions to the knowledge of Hippocamelus, Ctenomys and Myocastor from the middle Pleistocene of the Tarija Basin, Bolivia. Occasional Papers of the Museum of Natural History University of Kansas, 85:1-14.

Gasparini, G.M. in press. Records and stratigraphic ranges of South American Tayassuidae (Mammalia, Artiodactyla). Journal of Mammalian Evolution. doi. 10.1007/s10914-011-9172-z

Gasparini, G.M. \& Zurita, A.E. 2005. Primer registro fósil de Tayassu peccari (Link) (Mammalia, Artiodactyla) en la Argentina. Ameghiniana, 42:473-480.

Gasparini, G.M.; Kerber, L. \& Oliveira, E.V. 2009. Catagonus stenocephalus (Lund in Reinhardt, 1880) (Mammalia, Tayassuidae) in the Touro Passo Formation (late Pleistocene), Rio Grande do Sul, Brazil. Taxonomic and palaeoenvironmental comments. Neues Jahrbuch für Geologie und Paläontologie, Abhandlungen, 254:261-273. doi: 10.1127/0077-7749/2009/0016

Henriques, D.D.R. 1992. Os fósseis de Lestodon Gervais, 1885 (Edentata, Mylodontidae) da coleção de paleovertebrados do Museu Nacional/UFRJ. Estudo morfológico e comparativo. Programa de Pós-Graduação em Zoologia, Museu Nacional Rio de Janeiro. M.Sc. thesis, $182 \mathrm{p}$.

Kerber, L.; Lessa, G.; Ribeiro, A.M. \& Cartelle, C. 2011b. Reappraisal of the rodent Myocastor Kerr, 1782 (Rodentia, Hystricognathi) from the Brazilian Quaternary: preliminary data. In: CONGRESO LATINOAMERICANO DE PALEONTOLOGIA DE VERBRADOS, 4, 2011. Abstracts, San Juan, p. 199.

Kerber, L.; Lopes, R.P.; Vucetich, M.G.; Ribeiro, A.M. \& Pereira, J.C. 2011a. Chinchillidae and Dolichotinae rodents (Rodentia, Hystricognathi, Caviomorpha) from the late Pleistocene of southern Brazil. Revista Brasileira de Paleontologia, 14:229238. doi:10.4072/rbp.2011.3.03

Kerber, L. \& Oliveira. E.V. 2008a. Fósseis de vertebrados da Formação Touro Passo (Pleistoceno Superior), Rio Grande do Sul, Brasil: atualização dos dados e novas contribuições. Gaea, 4:49-64. doi:10.4013/gaea.20082.02

Kerber, L. \& Oliveira, E.V. 2008b. Presença de Equus (Perissodactyla, Equidae) e Neuryurus (Cingulata, Glyptodontidae) no Quaternário do município de Quaraí, oeste do Rio Grande do Sul. Cadernos de Pesquisa, Série Biologia, 20:18-25.

Kraglievich, L. 1940. Contribucion al conocimento de los ciervos fosiles del Uruguay. In: A. J. Torcelli \& C.A. Marelli (eds.) Obras de Geología y Paleontología III. Ministerio de Obras Públicas de la Provincia de Buenos Aires, Buenos Aires p. 143-221.

Labarca, R.O. \& López, P.G. 2006. Los mamíferos finipleistocénicos de la Formación Quebrada Quereo (IV Región - Chile): biogeografía, bioestratigrafía e inferencias paleoambientales. Mastozoologia Neotropical, 13:89-101. 
Lopes, R.P. 2009. Alterações post mortem (pseudopaleopatologias) em fósseis de mamíferos pleistocênicos do estado do Rio Grande do Sul, Brasil. Programa de Pós-Graduação em Geociências, Universidade Federal do Rio Grande do Sul, M.Sc. dissertation, $120 \mathrm{p}$.

Lopes, R.P. (in press). Biostratigraphy of the Pleistocene fossiliferous deposits of the southern Brazilian coastal area. Journal of Mammalian Evolution. doi: 10.1007/s10914-011-9173-y

Lopes, R.P. \& Buchmann, F.S.C. 2010. Pleistocene mammals from the southern Brazilian continental shelf. Journal of South American Earth Sciences, 31:17-27. doi: 10.1016/j. jsames.2010.11.003

Lopes, R.P; Buchmann, F.S.C; Caron, F. \& Itusarry, M.E. 2001. Tafonomia dos fósseis de vertebrados (megafauna extinta) encontrados ao longo das barrancas do arroio Chuí e linha de costa, RS, Brasil. Pesquisas em Geociências, 28:67-73.

Lopes, R.P.; Buchmann, F.S.C.; Caron, F. \& Itusarry, M.E.G. 2009. Barrancas fossilíferas do arroio Chuí, RS - Importante megafauna pleistocênica no extremo sul do Brasil. In: M. Winge; C. Schobbenhaus; M. Berbert-Born; E.T. Queiroz; D.A. Campos; C.R.G. Souza \& A.C.S. Fernandes (eds.). Sitios Geológicos e Paleontológicos do Brasil, CPRM, v. 2, p. 355-362.

Lopes, R.P.; Kinoshita, A.; Figueiredo, A.M.G.; Baffa, O. \& Buchmann, F.S.C. 2010. ESR dating of Pleistocene mammal teeth and its implications for the biostratigraphy and geologic evolution of the Rio Grande do Sul coastal plain, southern Brazil. Quaternary International, 212:213-222. doi:10.1016/j.quaint.2009.09.018

Lopes, R.P. \& Pereira, J.C. 2009. Fósseis de Antifer Ameghino (Artiodactyla: Cervidae) em depósitos pleistocênicos continentais da planície costeira do Estado do Rio Grande do Sul, Brasil, e suas implicações bioestratigráficas. In: JORNADAS ARGENTINAS DE PALEONTOLOGÍA DE VERTEBRADOS, 24, 2009. Libro de Resúmenes, San Rafael, p. 41-42.

Lopes, R.P. \& Pereira, J.C. 2010. Fossils of Scelidotheriinae Ameghino, 1904 (Xenarthra, Pilosa) in the Pleistocene deposits of Rio Grande do Sul, Brazil. Gaea, 6:44-52. doi: 10.4013/ gaea.2010.61.05

Marcon, G.T.G. 2008. Contribuição ao estudo dos Proboscidea (Mammalia, Gomphotheriidae) do Quaternário do estado Rio Grande do Sul, Brasil. Revista Universidade Guarulhos, 7:93-109.

Mayer, J.J. \& Brandt, P.N. 1982. Identity, distribution and natural history of the peccaries, Tayassuidae. In: M.A. Mares \& H.H. Genoways (eds.) Mammalian biology in South America, Pymatuning Symposia in Ecology, Connecticut, p. 433-455. (Special Publication Series 6).

Mayer, J.J. \& Wetzel, R.M. 1986. Catagonus wagneri. Mammalian Species, 259:1-5.

Menégaz, A.N. 2000. Los camélidos y cérvidos del Cuaternario Superior de la Región Pampeana. Doctorado en Ciencias Naturales, Universidade Nacional de La Plata, Ph.D. thesis, 240 p.

Menégaz, A.N. \& Ortiz Jaureguizar, E. 1995. Los artiodáctilos. In: M.T. Alberdi; G. Leone \& E.P. Tonni (eds.) Evolución biológica y climática de la región Pampeana durante los últimos cinco millones de años. Un ensayo de correlación con el Mediterráneo occidental. Madrid, Museo Nacional de Ciências Naturales, CSIC, p. 311-335. (Monografías 12).

Moreira, L.E. 1970. Primeira ocorrência de Smilodon populator Lund, 1842 no Estado do Rio Grande do Sul. Pesquisas, Zoologia, 23:25-35.

Oliveira, E.V. 1992. Mamíferos fósseis do Quaternário do Estado do Rio Grande do Sul, Brasil. Programa de Pós-Graduação em Geociências, Universidade Federal do Rio Grande do Sul,
M.Sc. thesis, 118p.

Oliveira, E.V. 1996. Mamíferos Xenarthra (Edentata) do Quaternário do estado do Rio Grande do Sul, Brasil. Ameghiniana, 33:65-75.

Oliveira, E.V. 1999. Quaternary vertebrates and climates of southern Brazil. In: J. Rabassa \& M. Saleme (eds.) Quaternary of South America and Antarctica Peninsula, A.A. Balkema, p. 61-73.

Oliveira, E.V. \& Drehmer, C.J. 1997. Sobre alguns restos de Pinnipedia-Otariidae (Mammalia, Carnivora) do Quaternário do Estado do Rio Grande do Sul, Brasil. Revista Universidade Guarulhos, 2:19-22.

Oliveira, E.V. \& Kerber, L. 2009. Paleontologia e aspectos geológicos das sucessões do final do Neógeno no sudoeste do Rio Grande do Sul, Brasil. Gaea, 5:21-34. doi: 10.4013/gaea.2009.51.03

Oliveira, E.V. \& Pereira, J.C. 2009. Intertropical cingulates (Mammalia, Xenarthra) from the Quaternary of southern Brazil: systematic and paleobiogeographical aspects. Revista Brasileira de Paleontologia, 12:167-178. doi:10.4072/rbp.2009.3.01

Oliveira, E.V.; Prevosti, F.J. \& Pereira, J.C. 2005. Protocyon troglodytes (Lund) (Mammalia, Carnivora) in the Late Pleistocene of Rio Grande do Sul and their paleoecological significance. Revista Brasileira de Paleontologia, 8:215-220.

Owen, R. 1861. Memoir on the Megatherium, or giant ground sloth of America (Megatherium americanum, Cuvier). London, Williams and Norgate, $84 \mathrm{p}$.

Pascual, R.; Ortega-Hinojosa, E.R.; Gondar, D. \& Tonni, E.P.1966. Las edades de Cenozóico mamalífero de la Provincia de Buenos Aires. In: A.V. Borrello (ed.) Paleontografia Bonaerense: Vertebrata. La Plata: Comisión de Investigaciones Cientificas. Fascículo IV, p. 03-27.

Paula Couto, C. 1975. Mamíferos fósseis do Quaternário do sudeste brasileiro. Boletim Paranaense de Geociências, 33:89-132.

Paula Couto, C. 1979. Tratado de Paleomastozoologia. Rio de Janeiro, Academia Brasileira de Ciências, 572 p.

Paula Couto, C. 1981. On an extinct peccary from the Pleistocene of Minas Gerais. Iheringia, (Série Geologia), 6:75-78.

Paula Couto, C. \& Souza Cunha, F.L.S. 1965. Nota preliminar sobre o reconhecimento geo-paleontológico do Rio Grande do Sul. Boletim da Divisão de Geologia e Mineralogia, 40:49-50.

Pereira, J.C.; Prevosti, F.J. \& Lopes, R.P. 2011. First record of Dusicyon avus Burmeister, 1866 (Carnívora, Canidae) in the fossiliferous deposits of Chuí Creek (Late Pleistocene), southern Brazil. In: CONGRESO LATINOAMERICANO DE PALEONTOLOGÍA DE VERTEBRADOS, 4, 2011. Resúmenes, San Juan, no 290.

Prado, J.L. \& Alberdi, M.T. 1994. A quantitative review of the horse Equus from South America. Paleontology, 37:459-481.

Ribeiro, R.C. \& Carvalho, I.S. 2009. Megafauna do Quaternário tardio de Baixa Grande, Bahia, Brasil. Anuário do Instituto de Geociências, UFRJ, 32:42-50.

Rodrigues, P.H. \& Ferigolo, J. 2004. Roedores pleistocênicos da planície costeira do Estado do Rio Grande do Sul, Brasil. Revista Brasileira de Paleontologia, 7:231-238.

Rodrigues, P.H.; Prevosti, F.J.; Ferigolo, J. \& Ribeiro, A.M. 2004. Novos materiais de Carnivora para o Pleistoceno do Estado do Rio Grande do Sul, Brasil. Revista Brasileira de Paleontologia, 7:77-86.

Scherer, C.S. \& Da Rosa, A.A.S. 2003. Um equídeo fóssil do Pleistoceno de Alegrete, RS, Brasil. Pesquisas em Geociências, 30:33-38.

Scherer, C.S.; Pitana, V.G. \& Ribeiro, A.M. 2009. Proterotheriidae and Macrauchenidae (Liptoterna, Mammalia) from the Pleistocene of Rio Grande do Sul State, Brazil. Revista Brasileira de Paleontologia, 12:231-246. doi:10.4072/rbp.2009.3.06.

Scherer, C.S.; Pitana, V.G. \& Ribeiro, A.M. 2007. Novas considerações sobre os Cervidae (Mammalia, Artiodactyla) no Quaternário do 
Rio Grande do Sul, Brasil. Ameghiniana, 43:39-40.

Schmitz, P.I.; Girelli, M. \& Rosa, A.O. 1997. Pesquisas arqueológicas em Santa Vitória do Palmar, RS. In: P.I. Schmitz (ed.) Arqueologia do Rio Grande do Sul, Brasil, São Leopoldo, Instituto Anchietano de Pesquisas, UNISINOS, 95 p. (Documentos 7).

Silva, D.D.; Sedor F.A. \& Oliveira, E.V. 2010. A presença de Catagonus e Tayassu (Artiodactyla, Tayassuidae) no Pleistoceno do Estado do Paraná, Brasil. Paleontologia em Destaque, edição especial, p. 112.

Soibelzon, L.H. 2004. Revisión Sistemática de los Tremarctinae (Carnivora, Ursidae) fósiles de América Del Sur. Revista del Museo Argentino de Ciencias Naturales (nueva série), 6:107-133.

Soibelzon, L.H.; Tonni, E.P. \& Bond, M. 2005. The fossil record of South American short-faced bears (Ursidae, Tremarctinae). Journal of South American Earth Sciences, 20:105-113. doi:10.1016/j.jsames.2005.07.005

Soliani Jr, E. 1973. Geologia da região de Santa Vitória do Palmar, RS, e a posição estratigráfica dos fósseis de mamíferos pleistocênicos. Programa de Pós-Graduação em Geociências, Universidade Federal do Rio Grande do Sul, M.Sc. thesis, 88p.

Souza Cunha, F.L.S. 1959. Mamíferos fósseis do Pleistoceno do Rio Grande do Sul. I - Ungulados. Rio de Janeiro, Departamento Nacional de Produção Mineral, Divisão de Geologia e Mineralogia, 47 p. (Boletim 202).

Souza Cunha, F.L.S. \& Magalhães, R.M.M. 1981. Cervídeos pleistocênicos de Santa Vitória do Palmar, Rio Grande do Sul, Brasil. In: CONGRESSO LATINO-AMERICANO DE PALEONTOLOGIA, 2, 1981. Anais, Porto Alegre, p. 795-803.

Toledo, P.M. 1986. Descrição do sincrânio de Eremotherium laurillardi Lund, 1842, taxonomia e paleobiogeografia. Programa de Pós-Graduação em Geociências, Universidade Federal do Rio Grande do Sul, M.Sc. thesis, 127 p.

Appendix 1. Updated list of fossil mammals from Chuí Creek.

Glyptodon clavipes Owen, 1838; Oliveira (1992)

Glyptodon reticulatus Owen, 1845; Oliveira (1992)

Doedicurus Burmeister, 1867; Oliveira (1992) and this paper

Panochthus Burmeister, 1866; Oliveira (1992)

Neuryurus rudis (Gervais, 1878); Lopes et al. (2011)

Mylodon darwini Owen, 1840; Oliveira (1992)

Lestodon Gervais, 1855; Oliveira (1992)

Catonyx cf. C. cuvieri Lund, 1839; Lopes \& Pereira (2010)

Eremotherium cf. E. laurillardi Lund, 1842; this paper

Propraopus aff. sulcatus Lund, 1842; Oliveira \& Pereira (2009)

Dasypus sp. Linnaeus, 1758; Oliveira \& Pereira (2009)

Pampatherium humboldti Lund, 1839; Oliveira \& Pereira (2009)

Holmesina paulacoutoi Cartelle \& Bohórquez, 1985; Oliveira \& Pereira (2009)

Toxodon platensis Owen, 1840; Lopes et al. (2001)

Macrauchenia patachonica Owen, 1838; Scherer et al. (2009)

Hemiauchenia aff. paradoxa Gervais \& Ameghino, 1880; Oliveira (1992)

Antifer Ameghino, 1889; this paper

Morenelaphus Carette, 1922; this paper

Catagonus Ameghino, 1904; this paper

Equus cf. E. (A.) neogaeus Lund, 1840; this paper

Hippidion Owen, 1869; this paper

Stegomastodon waringi Holland, 1920; Marcon (2008)

Microcavia Gervais \& Ameghino, 1880; Ubilla et al. (2008)

Myocastor cf. M. coypus (Molina, 1792); this paper

Dolichotinae Pocock, 1922; Kerber et al. (2011a)

Lagostomus cf. L. maximus (Desmarest, 1817); Kerber et al. (2011b)

Protocyon troglodites Lund, 1838; Oliveira et al. (2005)

Dusicyon avus Burmeister, 1866; Pereira et al. 2011

cf. Ursidae; this paper
Tomazelli, L.J.; Dillenburg, S.R. \&Villwock, J.A. 2000. Late Quaternary geological history of Rio Grande do Sul coastal plain, southern Brazil. Revista Brasileira de Geociências, 30:474-476.

Tonni, E.P. 2009. Los mamíferos del Cuaternario de la región pampeana de Buenos Aires, Argentina. In: A.M. Ribeiro; S.G. Bauermann \& C.S. Scherer (orgs.) Quaternário do Rio Grande do Sul-Integrando Conhecimentos. Monografias da Sociedade Brasileira de Paleontologia, 1:193-205.

Ubilla, M. 2004. Mammalian biostratigraphy of Pleistocene deposits in northern Uruguay, South America. Proceedings of the Geologist's Association, 115:347-357.

Ubilla, M.; Oliveira, E.V.; Rinderknecht, A. \& Pereira, J.C. 2008. The hystricognath rodent Microcavia in the Late Pleistocene of Brazil (Rio Grande do Sul, South America) (Mammalia: Caviidae). Biogeographic and paleoenvironmental implications. Neues Jahrbüch für Geologie und Paläontologie - Abhandlungen, 247:15-21. doi: 10.11.27/0077-7749/2008/0247-0015

Ubilla, M.; Perea, D.; Aguilar, C.G. \& Lorenzo, N. 2004. Late Pleistocene vertebrates from northern Uruguay: tools for bioestratigraphic, climatic and environmental reconstruction. Quaternary International, 114:129-142. doi:10.1016/S10406182(03)00048-X

Verzi, D.H.; Deschamps, C.M. \& Vucetich, M.G. 2002. Sistemática y antigüedad de Paramyocastor diligens (Ameghino, 1888) (Rodentia, Caviomorpha, Myocastoridae). Ameghiniana, 39:193-200.

Wetzel, R.M.; Dubos, R. E.; Martin, R. L. \& Myers, P. 1975. Catagonus, an "extinct" peccary alive in Paraguay. Science, 189:379-381.

Woods, C.A.; Contreras, L.; Willner-Chapman, G. \& Whidden, H.P. 1992. Myocastor coypus. Mammalian Species, 398:1-8.

Received in May, 2011; accepted in January, 2012. 